\title{
Low levels of sex hormone-binding globulin and hyperproinsulinemia as markers of increased pancreatic ß-cell demand in men
}

\section{A.F. Reis, \\ W.L. Miranda \\ and A.R. Chacra}

\author{
Disciplina de Endocrinologia, Departamento de Medicina, \\ Escola Paulista de Medicina, Universidade Federal de São Paulo, \\ São Paulo, SP, Brasil
}

\begin{abstract}
Correspondence
\section{A.F. Reis}

Rua João Pinheiro, 49

01429-001 São Paulo, SP

Brasil

Fax: + 55-11-889-0286

Research supported by FAPESP (No. 96/6780-0).
\end{abstract}

Received February 17, 1998 Accepted August 5, 1998

\section{Abstract}

Low levels of sex hormone-binding globulin (SHBG) are considered to be an indirect index of hyperinsulinemia, predicting the later onset of diabetes mellitus type 2 . In the insulin resistance state and in the presence of an increased pancreatic B-cell demand (e.g. obesity) both absolute and relative increases in proinsulin secretion occur. In the present study we investigated the correlation between SHBG and pancreatic $\beta$-cell secretion in men with different body compositions. Eighteen young men $(30.0 \pm 2.4$ years $)$ with normal glucose tolerance and body mass indexes (BMI) ranging from 22.6 to $43.2 \mathrm{~kg} / \mathrm{m}^{2}$ were submitted to an oral glucose tolerance test $(75 \mathrm{~g})$ and baseline and 120 min blood samples were used to determine insulin, proinsulin and Cpeptide by specific immunoassays. Baseline SHBG values were significantly correlated with baseline insulin $(\mathrm{r}=-0.58, \mathrm{P}<0.05)$, proinsulin $(\mathrm{r}=-0.47, \mathrm{P}<0.05), \mathrm{C}$-peptide $(\mathrm{r}=-0.55, \mathrm{P}<0.05)$ and also with proinsulin at $120 \mathrm{~min}$ after glucose load $(\mathrm{r}=-0.58, \mathrm{P}<0.05)$. Stepwise regression analysis revealed that proinsulin values at $120 \mathrm{~min}$ were the strongest predictor of SHBG $(\mathrm{r}=-0.58, \mathrm{P}<0.05)$. When subjects were divided into obese (BMI $\left.>28 \mathrm{~kg} / \mathrm{m}^{2}, \mathrm{~N}=8\right)$ and nonobese $(\mathrm{BMI} \leq 25$ $\mathrm{kg} / \mathrm{m}^{2}, \mathrm{~N}=10$ ) groups, significantly lower levels of SHBG were found in the obese subjects. The obese group had significantly higher baseline proinsulin, C-peptide and 120-min proinsulin and insulin levels. For the first time using a specific assay for insulin determination, a strong inverse correlation between insulinemia and SHBG levels was confirmed. The finding of a strong negative correlation between SHBG levels and pancreatic $\beta$-cell secretion, mainly for the 120-min post-glucose load proinsulin levels, reinforces the concept that low SHBG levels are a suitable marker of increased pancreatic $\beta$ cell demand.

\section{Introduction}

Sex hormone-binding globulin (SHBG), a glycoprotein produced by the liver, is responsible for the transport of sex steroids, mainly testosterone and dihydrotestosterone,
Key words

- Insulin

- Proinsulin

- Sex hormone-binding

globulin

- O besity whereas it binds to estradiol $\left(\mathrm{E}_{2}\right)$ with a much lower affinity (1). Hepatocyte SHBG production is under the influence of several factors which can either increase (thyroid hormones, estrogens) or reduce its levels (obesity, progestogen, growth hormone, pro- 
lactin) $(1,2)$. The inhibition of hepatic SHBG synthesis by insulin has been demonstrated in vitro (2). Many in vivo studies have shown a strong negative correlation between SHBG and insulinemia, leading to the speculation that the globulin could be a marker of insulin resistance $(3,4)$. A physiological model of this correlation can be found during puberty when a significant decrease in SHBG levels is observed along with a certain degree of insulin resistance $(2,5)$. The majority of the studies which tried to establish correlations between insulinemia and SHBG levels used insulin assays with high cross-reactivity with proinsulin.

For unknown reasons the correlation between sex steroids and insulinemia seems to be different for females and males $(2,6,7)$. In animals, sex differences in androgen levels and insulin sensitivity are confirmed by the impaired insulin sensitivity observed in female rats under testosterone treatment. At the same time, testosterone replacement improves insulin sensitivity in castrated male rats presenting insulin resistance (8). In humans these aspects have been less studied in men than in women.

High levels of proinsulin are observed when there is a dysfunctional or increased demand on pancreatic B-cells $(9,10)$. This pancreatic secretory disorder (hyperproinsulinemia) may precede the onset of diabetes mellitus, both type 1 and 2 (11-13). The proinsulin to insulin ratio and the absolute concentration of proinsulin predict the development of diabetes mellitus type 2, even after adjustment for other risk factors such as body mass index (BMI) and glucose tolerance status (10).

Although both SHBG and proinsulin are related to pancreatic $\beta$-cell dysfunction, there is no study trying to correlate these two proteins. Thus, the aim of the present study was to evaluate the correlation between endocrine pancreatic secretion and SHBG among young men with different body compositions.

\section{Subjects and Methods}

Eighteen white men in good health, ranging in age from 25 to 33 years $(30.0 \pm 2.4)$, with normal thyroid, hepatic and renal function (evaluated by measuring TSH, prothrombin time and creatinine, respectively) were studied. The subjects were not taking any drugs and none of them had taken part in a weight reduction program in the last four months. None of the subjects had symptoms or signs suggestive of sexual dysfunction or hypogonadism. Anthropometric measurements were performed on all participants, all barefoot and casually dressed, and included body weight, height, waist-to-hip ratio (WHR) (waist circumference was recorded at the narrowest point or at the umbilicus and hip circumference at the level of the greater trochanter) and BMI $\left(\mathrm{kg} / \mathrm{m}^{2}\right)$, which was calculated as current measured weight in kilograms divided by height in square meters. Body fat percentage was recorded using dual energy X-ray absorptiometry (DPX; Lunar Radiation Corporation, Madison, WI).

\section{Oral glucose tolerance test}

Dietary advice was given for 3 days before the oral glucose tolerance test (OGTT) to ensure an intake of at least $150 \mathrm{~g}$ of carbohydrate per day. The subjects were also advised to maintain their usual physical activities for at least one week before the test. After an overnight fast, a 75 g glucose load was administered and blood samples were drawn from an antecubital vein at baseline and at $120 \mathrm{~min}$ for the determination of plasma glucose, insulin, proinsulin and C-peptide. Blood samples were also drawn at baseline for SHBG determination. Only plasma glucose was measured immediately using the glucose oxidase method. The rest of the samples were centrifuged immediately after collection, and serum was stored at $-70^{\circ} \mathrm{C}$ until the time for assay. The definition of glucose tolerance was based on a $2-h$ 
oral glucose tolerance test according to World Health Organization criteria (14).

\section{Assays}

Specific insulin, proinsulin and C-peptide were measured in duplicate using commercial radioimmunoassay kits (Linco Research Inc., St. Charles, MO). For insulin the limit of sensitivity was $2 \mu \mathrm{U} / \mathrm{ml}$ and the intra- and interassay coefficients of variation (CV) were $<10 \%$. Cross-reactivity with human proinsulin was $<0.2 \%$ and with human insulin $100 \%$. The normal fasting range was $5-15 \mu \mathrm{U} / \mathrm{ml}$. In the proinsulin assay the limit of sensitivity was 2 pmol/l. Intra- and interassay coefficients of variation were $<10 \%$. Cross-reactivity with human insulin and human C-peptide was $<0.1 \%$. In the C-peptide assay the limit of sensitivity was $0.1 \mathrm{ng} / \mathrm{ml}$. Intra- and interassay coefficients of variation were $<10 \%$. Cross-reactivity with human proinsulin was $<4 \%$ and with human insulin $0 \%$. The molar ratio between proinsulin and insulin was calculated (proinsulin divided by insulin levels at baseline) after the conversion of insulin to $\mathrm{pmol} / 1$ using 6.0 as a conversion factor. SHBG was measured in duplicate using a commercial immunoradiometric assay (Diagnostic Systems Laboratories, Inc., Webster, TX). For SHBG the limit of sensitivity was $3 \mathrm{nmol} / \mathrm{l}$ and the intra-assay and interassay coefficients of variation were $<3.8 \%$ and $<11.6 \%$, respectively. The experimental protocol was approved by the Ethics Committee of Escola Paulista de Medicina, UNIFESP, and each subject gave written consent to participate in the study.

\section{Statistical analysis}

Data analysis was performed using a statistical software program (Jandel scientific software 2.0, Jandel Corporation, San Rafael, CA). The correlations between SHBG and the other variables were established using either Spearman's or Pearson's correlation test when data were normally distributed. A stepwise regression analysis using SHBG as dependent variable and insulin, proinsulin and C-peptide as independent variables was also performed. Comparisons between subgroups (obese and nonobese) were performed using the Mann-Whitney rank sum test when data were not normally distributed or the Student $t$-test when data were normally distributed. Results are reported as the means \pm SD. The level of significance was set at $\mathrm{P}<0.05$.

\section{Results}

The characteristics of the study group are shown in Table 1. The subjects enrolled in this study were young (age range, 25 to 33 years). There was a wide distribution of body composition and body fat, with nonobese and extremely obese subjects, as shown by ranges for BMI, \%fat and WHR of 22.6$43.2 \mathrm{~kg} / \mathrm{m}^{2}, 12.7-40.6 \%$ and $0.81-1.01$, respectively. It should be emphasized that the mean measurements for the group as a whole

Table 1 - Clinical and hormone characteristics of the subjects.

BMI, Body mass index; DPX, dual energy X-ray absorptiometry; WHR, waist-to-hip ratio; SHBG, sex hormone-binding globulin.

\begin{tabular}{lcc}
\hline & Mean \pm SD & Range \\
\hline BMI (kg/m²) & $28.8 \pm 6.3$ & $22.6-43.2$ \\
DPX (\%fat) & $24.5 \pm 8.9$ & $12.7-40.6$ \\
Waist $(\mathrm{cm})$ & $98 \pm 16$ & $81-130$ \\
WHR & $0.91 \pm 0.04$ & $0.81-1.01$ \\
Weight $(\mathrm{kg})$ & $91.7 \pm 22.0$ & $67.0-145.0$ \\
SHBG $(\mathrm{nmol} / \mathrm{l})$ & $38.7 \pm 13.4$ & $14.0-73.0$ \\
Fasting proinsulin $(\mathrm{pmol} / \mathrm{l})$ & $17.5 \pm 14.2$ & $8.0-70.0$ \\
120-min proinsulin $(\mathrm{pmol} / \mathrm{l})$ & $41.3 \pm 22.3$ & $12.0-92.0$ \\
Fasting C-peptide $(\mathrm{ng} / \mathrm{ml})$ & $2.1 \pm 1.0$ & $0.7-4.3$ \\
120-min C-peptide $(\mathrm{ng} / \mathrm{ml})$ & $5.9 \pm 3.5$ & $0.9-14.2$ \\
Proinsulin/insulin & $0.2 \pm 0.2$ & $0.02-0.97$ \\
Fasting glucose $(\mathrm{mg} / \mathrm{dl})$ & $93 \pm 8$ & $82-118$ \\
120-min glucose $(\mathrm{mg} / \mathrm{dl})$ & $101 \pm 22$ & $60-139$ \\
Fasting insulin $(\mu \mathrm{U} / \mathrm{ml})$ & $15.9 \pm 8.7$ & $7.0-36.0$ \\
120-min insulin $(\mu \mathrm{U} / \mathrm{ml})$ & $62.4 \pm 64.2$ & $10.8-247.7$
\end{tabular}


Table 2 - Correlations between SHBG and other variables.

$* \mathrm{P}<0.05$ (Pearson or Spearman test). For abbreviations, see Table 1.

\begin{tabular}{lll}
\hline BMI & $r=-0.41$ & $\mathrm{P}=0.08$ \\
DPX (\%fat) & $r=-0.53$ & $\mathrm{P}=0.02^{*}$ \\
Waist & $\mathrm{r}=-0.38$ & $\mathrm{P}=0.11$ \\
WHR & $\mathrm{r}=-0.53$ & $\mathrm{P}=0.02^{*}$ \\
Weight & $\mathrm{r}=-0.33$ & $\mathrm{P}=0.15$ \\
Fasting proinsulin & $\mathrm{r}=-0.47$ & $\mathrm{P}=0.047^{*}$ \\
120-min proinsulin & $\mathrm{r}=-0.58$ & $\mathrm{P}=0.01^{*}$ \\
Fasting C-peptide & $\mathrm{r}=-0.55$ & $\mathrm{P}=0.01^{*}$ \\
120-min C-peptide & $\mathrm{r}=-0.38$ & $\mathrm{P}=0.12$ \\
Proinsulin/insulin & $\mathrm{r}=0.10$ & $\mathrm{P}=0.68$ \\
Fasting glucose & $\mathrm{r}=-0.20$ & $\mathrm{P}=0.40$ \\
120-min glucose & $\mathrm{r}=-0.36$ & $\mathrm{P}=0.13$ \\
Fasting insulin & $\mathrm{r}=-0.53$ & $\mathrm{P}=0.02^{*}$ \\
120 min-insulin & $\mathrm{r}=-0.44$ & $\mathrm{P}=0.06$
\end{tabular}

were typical of obesity and fat excess. Mean values for BMI and \%fat were $28.8 \pm 6.3 \mathrm{~kg} /$ $\mathrm{m}^{2}$ and $24.5 \pm 8.9$, respectively. In agreement with the wide variation in body composition, pancreatic hormones at baseline and 120 min after the glucose load showed a wide distribution. Baseline insulin ranged from 7 to $36 \mu \mathrm{U} / \mathrm{ml}$ and post-glucose load levels ranged from 10 to $247 \mu \mathrm{U} / \mathrm{ml}$ (Table 1). This range of values was also observed for C-peptide and proinsulin. The whole group showed a tendency to high mean values due to the prevalence of obesity.

Table 2 shows the correlations between SHBG levels and other variables. SHBG values were inversely correlated with $\%$ fat and WHR, and no significant correlation was found between SHBG and BMI, waist circumference or weight. A significant negative correlation between fasting insulin, fast-

Figure 1 - Relationship between SHBG levels and 120-min proinsulin after a glucose load test in men.

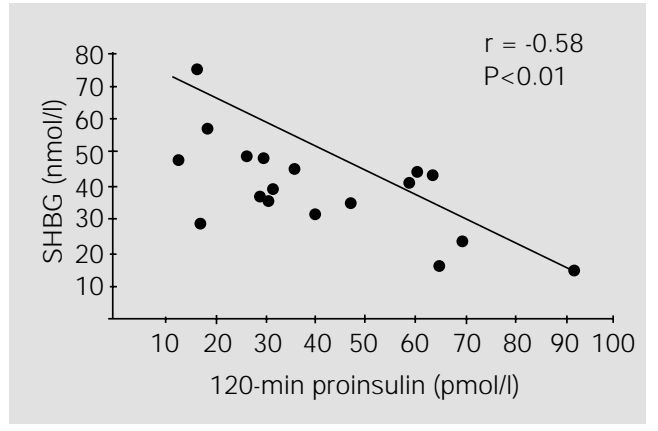

ing C-peptide, fasting and 120-min postglucose load proinsulin was found. There was no significant correlation between SHBG levels and the proinsulin/insulin molar ratio. Stepwise regression analysis showed that 120-min proinsulin was strongly correlated with, and thus was the best predictor of, SHBG $(r=-0.58 ; P=0.012)$ (Figure 1).

For further comparison of SHBG and pancreatic $\beta$-cell profile related to different body compositions the group was divided into nonobese subjects (BMI $\left.\leq 25 \mathrm{~kg} / \mathrm{m}^{2}\right)(\mathrm{N}$ $=10)$ and obese subjects (BMI $\left.>28 \mathrm{~kg} / \mathrm{m}^{2}\right)$ $(\mathrm{N}=8)$ (Table 3). There were marked differences in all anthropometric measurements (BMI, WHR, waist, weight and \%fat). Obese subjects showed significantly lower SHBG levels, higher 120-min insulin, baseline and 120-min proinsulin (Table 3) and baseline C-peptide levels than nonobese subjects. The proinsulin/insulin molar ratio was not significantly different between subgroups even though the obese group showed a higher ratio than the nonobese group $(0.26 \pm 0.29 \mathrm{vs}$ $0.16 \pm 0.09, \mathrm{P}=0.054)$. Even though the obese group showed higher 120-min glucose values, the difference was not statistically significant.

\section{Discussion}

In the present study we report for the first time a negative correlation between SHBG and baseline and post-glucose load proinsulin levels, reinforcing the previous concept that SHBG may be related to pancreatic $\beta$ cell secretion $(15,16)$. This study, performed using a highly specific insulin assay, has also confirmed previous studies which found a strong negative correlation between insulin and SHBG (6,17-19).

Low SHBG levels have been shown to predict diabetes mellitus type 2 in women $(3,6,20)$. It seems that decreased SHBG may correspond to an initial stage in the development of diabetes mellitus type 2, probably linked to hyperinsulinemia imposed on hepa- 
tocytes (4). A direct inhibitory effect of insulin on SHBG release was shown in vitro using cultures of a line of transformed human hepatocytes (HepG2) $(2,21)$. YkiJärvinen et al. (16) theorized that portal insulin concentrations rather than insulin sensitivity regulate $\mathrm{SHBG}$, and concluded that the globulin could only be used as a marker of insulin sensitivity in individuals with intact insulin secretion. In other studies, Peiris et al. (18) demonstrated the relationship of insulin secretory pulse frequency with SHBG without any association with insulin secretory pulse amplitude. Most of the studies on the establishment of in vivo and in vitro correlations between SHBG and insulinemia utilized insulin assays having high crossreactivity with proinsulin levels, possibly masking the proinsulin interrelationships.

It is well established that in states of pancreatic B-cell functional disorder there is an increase in proinsulin secretion $(10-13,22)$. The activity of proinsulin in stimulating peripheral disposal of glucose is approximately $1-8 \%$ that of insulin in the basal state $(23,24)$. When hyperproinsulinemia occurs this biological effect may be enhanced. We may assume that in both the above situations (portal insulinemia and secretory frequency of insulin pulses) proinsulin in addition to insulin may be concomitantly effective. In physiological conditions small amounts of proinsulin are released by pancreatic B-cell granules at a rate that can reach up to $15 \%$ of the total secretion. Furthermore, the insulin half-life is less than that of proinsulin, about 3.5 and $20 \mathrm{~min}$, respectively (24). The plasma proinsulin clearance is slower than that of insulin $(13,25)$. Although the effect of proinsulin is markedly lower than that of insulin on adipocytes, its effect on hepatocytes can reach $50 \%$ of the insulin effect $(26,27)$. We may assume that proinsulin may participate to some extent in the action of insulin on hepatocytes in terms of regulating hepatocytic SHBG release. Further in vitro investigations are required to clarify the role of proin- sulin as a direct regulator of hepatic SHBG release. In the present study we confirmed the negative correlation between greater pancreatic B-cell demand and low SHBG levels. When the stepwise regression test was applied, proinsulin was found to be the best predictor of SHBG. We must point out that we did not perform the insulin-glucose clamp test which is considered to be the gold standard for assaying insulin sensitivity. Thus, we could not confirm a correlation between SHBG levels and insulin sensitivity. However, the negative correlation found between SHBG levels and baseline insulinemia may suggest the existence of this correlation since in nondiabetic subjects insulin resistance and fasting insulin are moderately well correlated $(10,28)$.

Obesity has been pointed out as one of the causes of reduced SHBG levels; nevertheless, hyperinsulinemia and insulin resistance secondary to obesity seem to be determinant factors in this association. A fact that could indicate the absence of the role of obesity itself in reducing SHBG levels is the

\begin{tabular}{|c|c|c|}
\hline & $\begin{array}{c}\text { Nonobese } \\
(\mathrm{N}=10)\end{array}$ & $\begin{array}{l}\text { Obese } \\
(\mathrm{N}=8)\end{array}$ \\
\hline BMI $\left(\mathrm{kg} / \mathrm{m}^{2}\right)$ & $24.2 \pm 0.9$ & $34.5 \pm 5.2^{*}$ \\
\hline Waist (cm) & $85.8 \pm 4.5$ & $113.4 \pm 10.6 *$ \\
\hline WHR & $0.88 \pm 0.03$ & $0.96 \pm 0.03^{*}$ \\
\hline DPX (\%fat) & $18.0 \pm 5.0$ & $32.5 \pm 5.3^{*}$ \\
\hline Weight $(\mathrm{kg})$ & $76.4 \pm 6.0$ & $110.7 \pm 19.9 *$ \\
\hline Age (year) & $30.2 \pm 2.5$ & $31.1 \pm 2.6$ \\
\hline SHBG (nmol/l) & $44.6 \pm 13.0$ & $31.4 \pm 10.3^{*}$ \\
\hline Fasting insulin $(\mu \mathrm{U} / \mathrm{ml})$ & $11.8 \pm 3.4$ & $21.0 \pm 10.8$ \\
\hline 120-min insulin $(\mu \mathrm{U} / \mathrm{ml})$ & $25.5 \pm 12.7$ & $107.5 \pm 75.0^{*}$ \\
\hline Fasting proinsulin (pmol/l) & $11.6 \pm 3.0$ & $24.9 \pm 19.0^{*}$ \\
\hline 120-min proinsulin (pmol/l) & $27.4 \pm 14.2$ & $58.5 \pm 18.1^{*}$ \\
\hline Fasting C-peptide (ng/ml) & $1.7 \pm 0.6$ & $2.7 \pm 1.2^{*}$ \\
\hline 120-min C-peptide (ng/ml) & $4.6 \pm 2.9$ & $7.5 \pm 3.7$ \\
\hline Proinsulin/insulin & $0.16 \pm 0.09$ & $0.26 \pm 0.29$ \\
\hline Fasting glucose (mg/dl) & $94 \pm 9$ & $92 \pm 6$ \\
\hline 120-min glucose $(\mathrm{mg} / \mathrm{dl})$ & $94 \pm 21$ & $109 \pm 21$ \\
\hline
\end{tabular}


significant negative correlation between insulin concentration and SHBG in women of normal weight with polycystic ovary syndrome and insulin resistance (17). In our study a significant negative correlation between SHBG levels, WHR and \%fat (DPX) measurements was found (Table 2). WHR measurement has been indicated as an indirect insulin resistance index, reflecting a type of abdominal obesity (29-31). No correlation was observed between BMI and SHBG levels. Thus, we suggest that the association between obesity and low SHBG levels is at least in part dependent on hyperinsulinemia and insulin resistance typical of android obesity. The correlation between SHBG and insulin after adjustment for BMI has been reported $(8,31)$.

In conclusion, the present data show that SHBG values and pancreatic $\beta$-cell secretion are negatively correlated in men. Using a specific assay for the determination of insulin we confirmed literature reports of a strong negative correlation between insulinemia and SHBG levels. The presently described strong negative correlation between SHBG and proinsulin suggests that SHBG levels can be used as indirect markers of increased pancreatic B-cell demand. We assume that proinsulin may have some degree of hepatocyte activity reducing SHBG synthesis, mainly in hyperproinsulinemic states. Further in vitro studies are required to elucidate this point.

\section{References}

1. Rosner W (1990). The functions of corticosteroid-binding globulin and sex hormone-binding globulin; recent advances. Endocrine Reviews, 11: 80-91.

2. Plymate SR, Matej LA, J ones RE \& Friedl KE (1988). Inhibition of sex hormone-binding globulin production in the human hepatoma (Hep G2) cell line by insulin and prolactin. J ournal of Clinical Endocrinology and Metabolism, 67: 460-464.

3. Preziosi $P$, Barrett-Connor $E, P a p o z ~ L$, Roger M, Saint-Paul M, Nahoul K \& Simon D (1993). Interrelation between plasma sex hormone-binding globulin and plasma insulin in healthy adult women: the telecom study. J ournal of Clinical Endocrinology and Metabolism, 76: 283-287.

4. Nestler J E (1993). Editorial: sex hormonebinding globulin: a marker for hyperinsulinemia and/or insulin resistance? J ournal of Clinical Endocrinology and Metabolism, 76: 273-274.

5. Caprio S, Plewe G, Diamond MP, Simonson DC, Boulware SD, Sherwin RS \& Tamborlane WV (1989). Increased insulin secretion in puberty: a compensatory response to reductions in insulin sensitivity. J ournal of Pediatrics, 114: 963-967.

6. Haffner SM, Valdez RA, Morales PA, Hazuda HP \& Stern MP (1993). Decreased sex hormone-binding globulin predicts noninsulin-dependent diabetes mellitus in women but not in men. J ournal of Clinical Endocrinology and Metabolism, 77: 56-60.
7. Andersson $B, M$ arin $P$, Lissner $L$, Vermeulen A \& Björmtorp P (1994). Testosterone concentrations in women and men with NIDDM. Diabetes Care, 17: 405411.

8. Haffner SM, Karhapää P, Mykkänen L \& Laakso M (1994). Insulin resistance, body fat distribution, and sex hormones in men. Diabetes, 43: 212-219.

9. Shimizu M, Kawazu S, Tomono S, Ohno T, Utsugi T, Kato N, Ishii C, Ito Y \& Murata $K$ (1996). Age-related alteration of pancreatic B-cell function: Increased proinsulin and proinsulin-to-insulin molar ratio in elderly, but not in obese subjects without glucose intolerance. Diabetes Care, 19: 811.

10. Haffner SM, Gonzalez C, Mykkänen L \& Stern M (1997). Total immunoreactive proinsulin, immunoreactive insulin and specific insulin in relation to conversion to NIDDM: the Mexico City diabetes study. Diabetologia, 40: 830-837.

11. Røder ME, Knip M, Hartling SG, Karjalainen J , Akerblom HK, Binder C \& The Childhood Diabetes in Finland Study Group (1994). Disproportionately elevated proinsulin levels precede the onset of insulin-dependent diabetes mellitus in siblings with low first phase insulin responses. J ournal of Clinical Endocrinology and Metabolism, 79: 1570-1575.

12. Kahn SE, Leonetti DL, Prigeon RL, Boyko EJ , Bergstrom RW \& Fujimoto WY (1995).
Proinsulin as a marker for the development of NIDDM in J apanese-American men. Diabetes, 44: 173-179.

13. Dalbosco IS, Coifman R, Moisés RCS Vieira J GH \& Russo EMK (1995). Influência da obesidade e da glicemia nos níveis de pró-insulina durante o teste oral de tolerância à glicose. Arquivos Brasileiros de Endocrinologia e Metabologia, 39: 8993.

14. WHO - Expert Committee on Diabetes Mellitus (1980). Second Report. WHO. Technical Report Series, 646: 1-80.

15. Fendri S, Arlot S, Marcelli J M, Dubreuil A \& Lalau J D (1994). Relationship between insulin sensitivity and circulating sex hormone-binding globulin levels in hyperandrogenic obese women. International J ournal of Obesity, 18: 755-759.

16. Yki-J ärvinen $\mathrm{H}, \mathrm{M}$ äkimattila $\mathrm{S}$, Utriainen $\mathrm{T}$ \& Rutanen EM (1995). Portal insulin concentrations rather than insulin sensitivity regulate serum sex hormone-binding globulin and insulin-like growth factor binding protein 1 in vivo. J ournal of Clinical Endocrinology and Metabolism, 80: 3227-3232.

17. Hamilton-Fairley $D$, White $D$, Griffiths $M$, Anyaoku V, Koistinen R, Seppälä M \& Franks S (1995). Diurnal variation of sex hormone binding globulin and insulin-like growth factor binding protein-1 in women with polycystic ovary syndrome. Clinical Endocrinology, 43: 159-165. 
18. Peiris LN, Stagner J I, Plymate SR, Vogel RL, Heck M \& Samols E (1993). Relationship of insulin secretory pulses to sex hormone-binding globulin in normal men. $J$ ournal of Clinical Endocrinology and Metabolism, 76: 279-282.

19. Pasquali $R$, Casimiri F, De lasio $R$, Mesini $P$, Boschi S, Chierici R, Flamia R, Biscotti $M \&$ Vicennati V (1995). Insulin regulates testosterone and sex hormone-binding globulin concentrations in adult normal weight and obese men. J ournal of Clinical Endocrinology and Metabolism, 80: 654658.

20. Lindstedt $G$, Lundberg $P A$, Lapidus $L$, Lundgren $\mathrm{H}$, Bengtsson $\mathrm{C} \&$ Björntorp $\mathrm{P}$ (1991). Low sex-hormone-binding globulin concentration as independent risk factor for development of NIDDM : 12-yr follow-up of population study of women in Gothenburg, Sweden. Diabetes, 40: 123128.

21. Loukovaara M, Carson M \& Adlercreutz H (1995). Regulation of sex hormone-binding globulin secretion and gene expression by cycloheximide in vitro. J ournal of Steroid Biochemistry and Molecular Biology, 54: 141-146.
22. Haffner SM, Mykkänen L, Valdez RA, Stern MP, Holloway DL, Monterrosa A \& Bowsher RR (1994). Disproportionately increased proinsulin levels are associated with the insulin resistance syndrome. $\mathrm{J}$ ournal of Clinical Endocrinology and Metabolism, 79: 1806-1810.

23. Yudkin J S, Denver AE, Mohamed-Ali V, Ramaiya KL, Nagi DK, Goubet S, McLarty DG \& Swai A (1997). The relationship of concentration of insulin and proinsulin-like molecules with coronary heart disease prevalence and incidence. Diabetes Care, 20: 1093-1100.

24. Warren-Perry MG, Manley SE, Ostrega D, Polonsky K, Mussett S, Brown P \& Turner RC (1997). A novel point mutation in the insulin gene giving rise to hyperproinsulinemia. J ournal of Clinical Endocrinology and Metabolism, 82: 1629-1631.

25. Horvitz DL, Starr JI, Mako ME, Blackard WG \& Rubenstein AH (1975). Proinsulin, insulin, and C-peptide concentrations in human portal and peripheral blood. J ournal of Clinical Investigation, 55: 12781283.

26. Glauber HS, Henry RR, Wallace $P$, Frank $\mathrm{BH}$, Gallowaw J A, Cohen RM \& Olefsky
J M (1987). The effects of biosynthetic human proinsulin on carbohydrate metabolism in non-insulin-dependent diabetes mellitus. New England J ournal of Medicine, 316: 443-449.

27. Robbins DC, Tager HS \& Rubenstein $\mathrm{AH}$ (1984). Biologic and clinical importance of proinsulin. New England J ournal of Medicine, 310: 1165-1175.

28. Haffner SM, Miettinen $\mathrm{H} \&$ Stern MP (1997). The homeostasis model in the San Antonio heart study. Diabetes Care, 20: 1087-1092.

29. Ludvik B, Nolan J J, Baloga J , Sacks D \& Olefsky J (1995). Effect of obesity on insulin resistance in normal subjects and patients with NIDDM. Diabetes, 44: 1121-1125.

30. Banerji MA, Chaiken RL, Gordon D, Kral J G \& Lebovitz HE (1995). Does intra-abdominal adipose tissue in black men determine whether NIDDM is insulin-resistant or insulin-sensitive? Diabetes, 44 141-146.

31. Phillips GB (1993). Relationship between serum sex hormones and the glucoseinsulin-lipid defect in men with obesity. Metabolism, 42: 116-120. 


\section{AN EVOLUTION IN BIOMEDICAL}

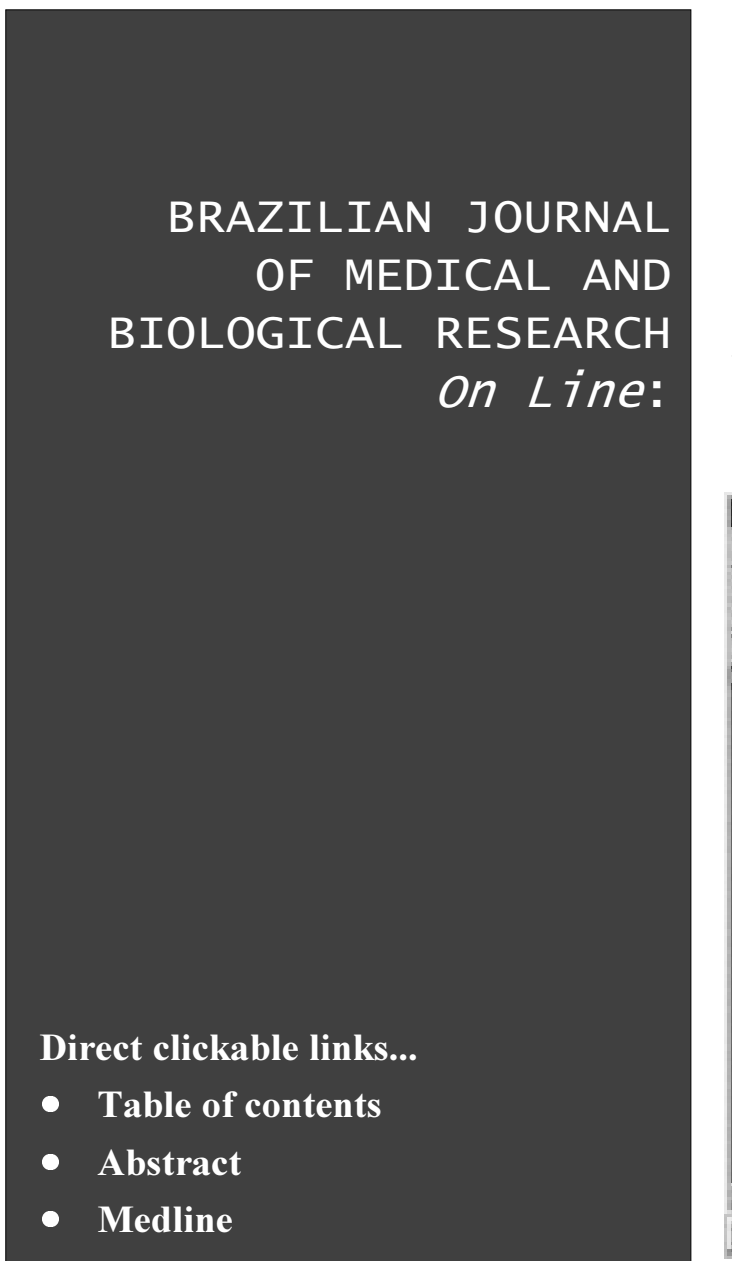

\section{COMMUNICATION}

\section{http://www.scielo.br/bjmbr.htm}

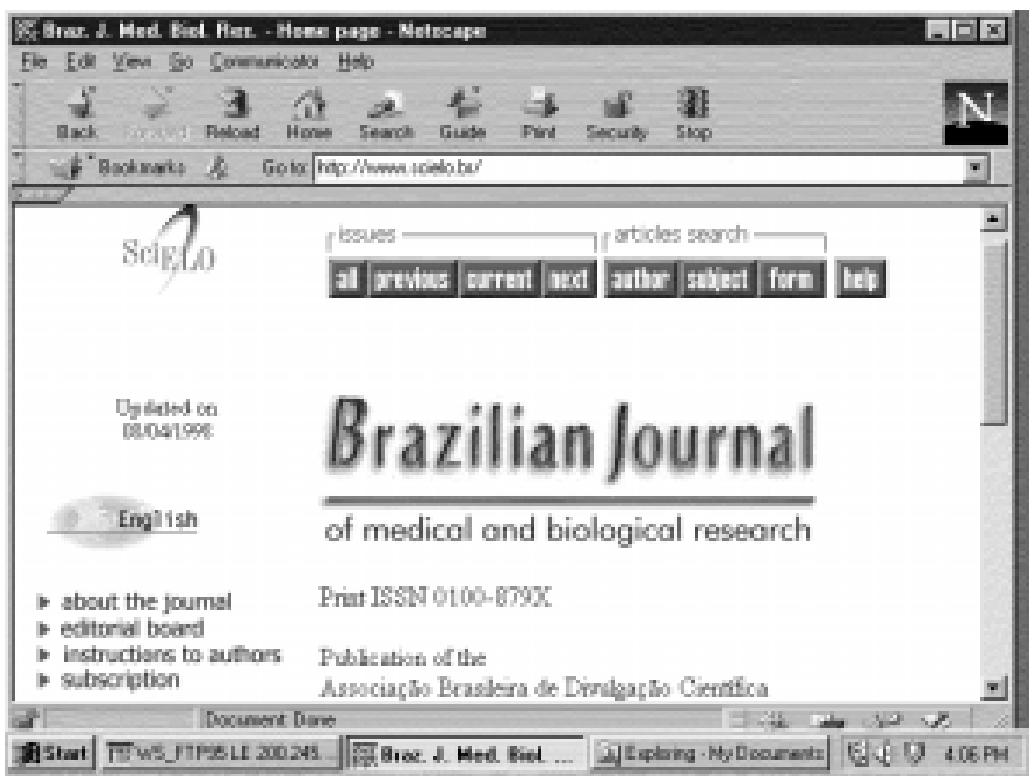

\section{Searchable....}

- Search by Keywords, Author, Subject

View or print...

- Abstract

- Full text

- PDF (Adobe Acrobat) files

Questions? Please contact our Office

Brazilian Journal of Medical and Biological Research

Av. Bandeirantes, 3.900

14049-900 Ribeirão Preto, SP, Brasil

Telephone and Fax

Brasil: (016) 633-3825

Others: (55) 16-633-3825

Email: bjournal@,fmrp.usp.br 